\title{
Isolated lipase and colipase deficiency in two brothers
}

\author{
M Ligumsky, E Granot, D Branski, H Stankiewicz, R Goldstein
}

\begin{abstract}
Two brothers of Arab origin, aged 15 and 10 years, with isolated congenital lipase and colipase deficiency are described. Both were normally developed with a history of passing greasy stools since early infancy. Both have remarkable steatorrhoea and low serum carotene and vitamin $\mathbf{E}$ concentrations. After exocrine pancreatic stimulation, lipase and colipase activities in the duodenal fluid were almost completely absent, while amylase trypsin, bile salt, and $\mathrm{pH}$ values were normal. No other aetiology for exocrine pancreatic insufficiency was found. This is the first report of congenital combined lipase and colipase deficiency in two brothers.
\end{abstract}

Congenital isolated pancreatic enzyme deficiencies are rare causes of malabsorption in infancy and childhood. ${ }^{1}$ The only occurrence of isolated colipase deficiency in two brothers was reported by Hilderbrand et $a l,{ }^{2}$ while only one case of isolated combined congenital lipase-colipase deficiency was published by Fayez et al. ${ }^{3}$ To the best of our knowledge, the present report is the first to document isolated lipase-colipase deficiency in two brothers.

\section{Case reports}

Two brothers of Arab origin, born to non-related parents, are described. The eldest, patient 1 , is 15 years old. From birth, his mother noted intermittent greasy-oily stools, especially when he was on a fat rich diet. The stool had an offensive odour, but no soiling was noted. His development had been uneventful and his weight and height were both above the 50th percentile. Physical examination was normal. Blood tests; including haemoglobin, leucocytes, and platelets; liver function tests; calcium; and phosphorus were normal. Plasma cholesterol was 3.6 $\mathrm{mmol} / \mathrm{l}$ and triglycerides $0.78 \mathrm{mmol} / \mathrm{l}$. Prothrombin time was $77 \%$. Serum carotene was $35 \mathrm{U}$ (normal 180-250 U) and vitamin E was $0.15 \mu \mathrm{mol} / 1$ (normal $0.5-1.0 \mu \mathrm{mol} / \mathrm{l}$ ). Serum iron, vitamin $B_{12}$, and folic acid values were normal. A three day stool collection yielded $32 \mathrm{~g}$ of fat per day on an average daily intake of 100 $107 \mathrm{~g}$ fat ( $70 \%$ fat absorption). After inquiry of close family members, a younger brother was found to have a similar medical history.

Patient 2, the younger brother, aged 10 years, had had greasy-oily stools since birth. His physical development was normal. Stool fat collection yielded $14 \mathrm{~g}$ of fat per day on his regular diet containing $67 \mathrm{~g}$ of fat $(79 \%$ absorption). Complete blood count, liver function tests, calcium, and phosphorus values were normal. Prothrombin time was $82 \%$, serum carotene $20 \mathrm{U}$, and vitamin E $0.34 \mu \mathrm{mol} / \mathrm{l}$.
Results of pancreatic stimulation test (pancreozymin-secretin test) were consistent with isolated lipase and colipase deficiencies in both brothers (Table). Stool fat examined in three other siblings showed normal daily fat excretion. Vitamin E supplements together with pancreatic enzyme preparation were prescribed. Both patients, however, were lost to follow up.

\section{Methods}

PANCREOZYMIN SECRETIN STIMULATION TEST

A pancreatic stimulation test was performed as previously described. ${ }^{45}$ After an overnight fast, a nasoduodenal tube was placed under fluoroscopy into the third part of the duodenum. A basal sample of the duodenal fluid was collected into ice cold flasks during the first 10 minutes (basal). Pancreozymin (Kabi Diagnostica, Studsvik, Sweden) $2 \mathrm{U} / \mathrm{kg}$ was then slowly injected intravenously and three duodenal fluid samples at 10 minute intervals were collected as above. Subsequently, three more samples of duodenal aspirate were collected every 10 minutes following intravenous administration of secretin (Kabi $2 \mathrm{U} / \mathrm{kg}$ ). The volume and $\mathrm{pH}$ value for each sample were determined immediately. Samples were then stored at $-20^{\circ} \mathrm{C}$ until enzyme activity determinations.

\section{ENZYME DETERMINATIONS}

Trypsin was measured by a fluorimetric technique as described by Roth, ${ }^{6}$ using bovine trypsin (Sigma, Israel) as standard and expressed in $\mu \mathrm{g} / \mathrm{ml}$. Amylase was determined by the chromogenic enzymatic test adapted for duodenal juice (Phadebas amylase test, Pharmacia Diagnostics AB, Uppsala, Sweden) and expressed in $U / \mathrm{ml}$. One unit of amylase activity is defined as the amount of enzyme catalysing the hydrolysis of $1 \mu \mathrm{mol}$ glucosidic linkage per minute at $37^{\circ} \mathrm{C}$. Bile salts were determined by an enzymatic spectrophotometric test for total bile acids (Sterognost -3a PhO, Nycomed AS, Oslo, Norway). Lipase activity in the duodenal samples was measured by turbidimetry according to Tietz et al, ${ }^{7}$ using absorbance measurements by spectrophotometry. ${ }^{8}$ Triolein $0.3 \mathrm{mM}$ at $\mathrm{pH} 9 \cdot 0$ was used as substrate in the presence of $15 \mathrm{mM}$ taurodeoxycholate and in excess of colipase (Sigma, Israel) 10-100 pmol. One unit of lipase activity is defined as the amount of enzyme that catalyses the transformation of $1 \mu \mathrm{mol}$ triolein per minute at $37^{\circ} \mathrm{C}$.

Colipase activity was measured by its ability to reactivate bile salt inhibited lipase. ${ }^{9}$ Duodenal samples were heated to $80^{\circ} \mathrm{C}$ for 15 minutes for endogenous lipase inactivation, then added to a solution containing a standard amount of 100 pmol lipase (Sigma, Israel) derived from porcine 


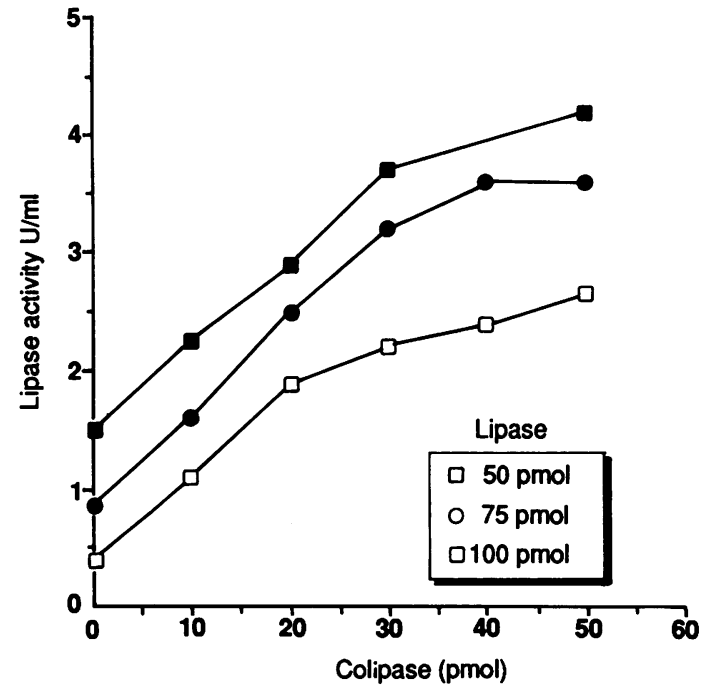

Lipase activity $(\mathrm{U} / \mathrm{ml})$ as a function of colipase dosage (10-50 pmol) in the presence of standard doses of lipase (50, 75 , and 100 pmol). Lipase activity was measured by turbidimetry using $0.3 \mathrm{M}$ triolein as a substrate in the presence of $15 \mathrm{mM}$ taurodeoxycholate and colipase in excess. One unit of lipase activity is defined as the amount of enzyme that catalyses the transformation of 1 mol of triolein per minute at $37^{\circ} \mathrm{C}$.

pancreas (MW 50000) and the restored lipase activity was determined by absorbance as described above. This activity was then transformed to moles of colipase (MW 11000) according to a standard curve (Figure).

\section{Results}

Amylase and trypsin activities showed normal responses to the pancreozymin secretin stimulation test, as well as the changes in $\mathrm{pH}$ and bile salt concentrations (Table). Lipase response in both patients showed only a trace - not more than $1 \mathrm{U} / \mathrm{ml}$ - (without exogenous colipase) which is less than $1.5 \%$ of the normal lipase activity (normal maximal response $>80 \mathrm{U} / \mathrm{ml}$ ). Colipase was unmeasurable in the duodenal fluid of the older brother (patient 1) and only a trace activity was detected in that of the younger (patient 2).

\section{Discussion}

Congenital, isolated exocrine pancreatic enzyme deficiencies are rare causes of malabsorption in infancy and childhood. ${ }^{\prime}$ Isolated lipase

Pancreatic stimulation test

\begin{tabular}{|c|c|c|c|c|c|c|c|}
\hline \multirow[b]{2}{*}{ Patients } & \multirow[b]{2}{*}{ Basal } & \multicolumn{3}{|c|}{ Pancreozymin } & \multicolumn{3}{|c|}{ Secretin } \\
\hline & & $10 \min$ & $20 \min$ & $30 \mathrm{~min}$ & $40 \mathrm{~min}$ & $50 \min$ & $60 \mathrm{~min}$ \\
\hline $\begin{array}{l}l: \\
\text { Volume }(\mathrm{ml}) \\
\text { Amylase }(\mathrm{U} / \mathrm{ml}) \\
\text { Trypsin }(\mu \mathrm{g} / \mathrm{ml}) \\
\text { pH } \\
\text { Bile salts }(\mathrm{mM}) \\
\text { Lipase }(\mathrm{U} / \mathrm{ml}) \\
\text { Colipase }(\mathrm{mM})\end{array}$ & $\begin{array}{c}2 \\
202 \\
64 \\
6 \cdot 5 \\
0 \cdot 2 \\
0.6 \\
0\end{array}$ & $\begin{array}{c}12 \\
300 \\
1010 \\
6 \cdot 6 \\
4 \cdot 2 \\
0 \cdot 6 \\
0\end{array}$ & $\begin{array}{c}10 \\
242 \\
440 \\
7 \cdot 3 \\
20 \\
5 \cdot 1 \\
0\end{array}$ & $\begin{array}{c}6 \\
227 \\
290 \\
7 \cdot 2 \\
30 \\
1.9 \\
0\end{array}$ & $\begin{array}{c}40 \\
207 \\
260 \\
7 \cdot 8 \\
12 \\
1 \cdot 4 \\
0\end{array}$ & $\begin{array}{c}55 \\
87 \\
148 \\
7 \cdot 5 \\
1 \cdot 5 \\
1 \cdot 2 \\
0\end{array}$ & $\begin{array}{l}23 \\
67 \\
56 \\
8 \cdot 0 \\
0 \cdot 8 \\
0 \cdot 8 \\
0\end{array}$ \\
\hline $\begin{array}{l}2: \\
\text { Volume }(\mathrm{ml}) \\
\text { Amylase }(\mathrm{U} / \mathrm{ml}) \\
\text { Trypsin }(\mu \mathrm{g} / \mathrm{ml}) \\
\text { pH } \\
\text { Bile salts }(\mathrm{mM}) \\
\text { Lipase }(\mathrm{U} / \mathrm{ml}) \\
\text { Colipase }(\mathrm{mM})\end{array}$ & $\begin{array}{c}12 \\
352 \\
270 \\
4 \cdot 6 \\
4 \cdot 6 \\
4 \cdot 5 \\
28\end{array}$ & $\begin{array}{c}24 \\
369 \\
660 \\
6.9 \\
111 \\
1.9 \\
27\end{array}$ & $\begin{array}{c}10 \\
297 \\
350 \\
7 \cdot 3 \\
90 \\
0 \\
-\end{array}$ & $\begin{array}{c}12 \\
279 \\
232 \\
6 \cdot 9 \\
15 \\
0 \\
14\end{array}$ & $\begin{array}{c}25 \\
331 \\
220 \\
7 \cdot 0 \\
3 \cdot 8 \\
0 \\
3\end{array}$ & $\begin{array}{c}25 \\
207 \\
80 \\
7 \cdot 1 \\
0 \cdot 4 \\
0 \\
0\end{array}$ & $\begin{array}{c}25 \\
160 \\
47 \\
7 \cdot 3 \\
0 \\
0 \\
0\end{array}$ \\
\hline
\end{tabular}

deficiency was reported in 12 patients $^{10-17}$ in whom other more common causes of pancreatic disease were ruled out. In addition to its functional absence, no immunologically active lipase could be detected. ${ }^{18}$ The most characteristic manifestation was the passage of greasy-oily stools, often associated with soiling.

Colipase is a heat stable factor which was found to facilitate lipolysis in the presence of lipase. ${ }^{19} 20$ This is a glycoprotein secreted by the pancreas as procolipase which is cleaved by proteolytic enzymes, mainly trypsin, to result in the active moiety. ${ }^{21}$ It is the only factor that can activate lipase in the presence of bile acids. Colipase deficiency was implicated in the pathogenesis of some childhood onset pancreatic insufficiency. ${ }^{82223}$ Congenital isolated colipase deficiency was reported only in two Assyrian brothers born in a consanguineous marriage. ${ }^{2}$ Their development was normal and no other pancreatic enzyme deficiencies were detected. Fayez $e t a l^{3}$ described the first case of combined isolated lipase and colipase deficiency. The measured activity of both enzymes was less than $2 \%$ of that found in normal control subjects. To the best of our knowledge the present report is the first to describe combined lipase and colipase deficiency in two brothers. In both, the residual lipase activity of the duodenal fluid was found to be less than $1.5 \%$ of that of the control, while the colipase activity was almost completely absent. The possibility of procolipase deficiency is valid since the $\mathrm{pH}$ and the tryptic activity which cleaves the procolipase were normal in the duodenal aspirate. Although steatorrhoea prevailed, probably since birth, growth and development were uneventful and no clinical signs of deficiency of any lipid soluble vitamin were noted. Serum carotene and vitamin E concentrations, however, were significantly decreased in both brothers. In patients with chronic severe fat malabsorption and vitamin $\mathrm{E}$ deficiency, a syndrome of progressive neuromuscular disorder characterised by ataxia, incoordination, areflexia, loss of vibratory sensation, and variable ophthalmoplegia develops. ${ }^{24} \mathrm{We}$ believe that prolonged vitamin $\mathrm{E}$ deficiency would have eventually induced the neurological syndrome in both brothers. Therefore, aggressive vitamin $\mathrm{E}$ therapy as well as pancreatic extract is indicated in order to prevent any neurological degeneration. Although lipase and colipase activities in the pancreatic secretions of both brothers were almost completely absent, fat absorption was $70 \%$ and $79 \%$ of fat intake, respectively. This implies that in these patients extrapancreatic sources of lipase, such as lingual and gastric lipase $^{2526}$ may have an important compensating role in fat digestion, thereby preventing the expected severe fat malabsorption and its morbid sequelae.

1 Lerner A, Heitinger LA, Lebental E. Hereditary abnormalities of pancreatic function. In: Go VLW, et al, eds. The exocrine pancreas. New York: Raven Press, 1986: 819-27.

2 Hilderbrand $H$. Borgstrom B, Bokassy A, ErlansonAlbertsson C, Helin I. Isolated colipase deficiency in two brothers. Gut 1982; 23: 243-6.

3 Fayez K, Ghishan J, Moran R, Durie PR, Greene HL. Isolated congenital lipase-colipase deficiency. Gastroenterology 1984 86: $1580-2$.

4 Schwachman H, Lebenthal E, Khaw KT. Recurrent acute pancreatitis in patients with cystic fibrosis with normal pancreatic enzymes. Pediatrics 1975; 55: 86-95. 
5 Lebenthal E, Lee PC. Development of functional response in human exocrine pancreas. Pediatrics 1980; 66: 556-60.

6 Roth M. Dosage fluorimetrique de la trypsine. Clin Chim Acta 1963; 8: 574-8.

7 Tietz NW, Shuey DF, Astler JR. Turbidimetric measurement of lipase activity - Problems and some solutions. Clin Chem 1987; 33: 1624-9.

8 Gaskin KJ, Durie PR, Hill RE, Lee LM, Forstner GG Colipase and maximally activated pancreatic lipase in norma subjects and patients with steatorrhea. $\mathcal{F}$ Clin Invest 1982; 69: 427-34.

9 Borgstrom B, Hildebrand H. Lipase and colipase activities of human small intestinal contents after a liquid test meal. Scand F Gastroenterol 1975; 10: 585-91.

10 Sheldon W. Congenital pancreatic lipase deficiency. Arch Dis Child 1964; 39: 268-71.

11 Rey J, Frezal J, Royer P, Lamy M. L'absence congenital de lipase pancreatique. Arch Fr Pediatr 1966; 32: 5-12.

12 Muller DPR, McCollum JPK, Trompeter RS, Harries JT. Studies on the mechanism of fat absorption in congenital isolated lipase deficiency [Abstract]. Gut 1975; 16: 838 .

13 Figarella C, DeCaro A, Deprez P, Bouvry H, Bernier J. Un nouveau case de deficience congentiale en lipase pancreatique avec presence de colipase. Gastroenterol Clin Biol 1979; 3: 43-

14 Figarella C, DeCaro A, Leupold D, Poley J. Congenital pancreatic lipase deficiency. $\mathcal{F}$ Pediatr 1980; 96 : 412-6.

15 Balzer E. Angeborener Mangel an Pankreaslipase. Z Gastroenterol 1967; 5: 239-46.

16 Larbre F, Hartman E, Cotton JB, Mathieu M, Charrat A, Moreau P. Diarrhee chronique par absence de lipase pancreatique. Pediatrie 1969; 24: 807-13.
17 Verger P, Babin R, Guillard JM, Babin JP, Cixous P, Laigle JL. Steatorrhee chronique de l'enfant par insufficience congenitale de la lipase pancreatique. Arch Fr Pediatr 1971; 28: 992

18 Figarella C, Negri GA, Sarles H. Presence of colipase in congenital pancreatic lipase deficiency. Biochim Biophys Acta 1972; 280: 205-10.

19 Rosenheim O. On pancreatic lipase. I. The accelerating action of hemolytic substances and their inhibition by cholesteria.

20 Basky B, Klein E, Lever WF. Lipase of blood and tissues. II. Purification and properties of pancreatic lipase. Arch Biochem Biophys 1963; 102: 201-9.

21 Borgstrom B, Wielach T, Erlanson-Albertson C. Evidence for pancreatic pro-colipase and its activation by trypsin. FEBS Lett 1979; 108: 407-10.

22 Borgstrom B. Relative colipase deficiency as a cause of fat malabsorption in humans and the importance of the law of mass action for clinical medicine. Gastroenterology $1984 ; 86$ : 194-6.

23 Gaskin K, Durie P, Lee L, Hill RE, Forstner G. Colipase and lipase secretion in childhood onset pancreatic insufficiency. Gastroenterology 1984; 86: 1-7.

24 Guggenheim MA, Ringel SP, Silverman A, Grabert BE. Progressive neuromuscular disease in children with chronic cholestasis and vitamin E deficiency. $\mathcal{F}$ Pediatr 1982; 100 51-8.

25 Liao TH, Hamosh P, Hamosh M. Fat digestion by lingua lipase: mechanism of lipolysis in the stomach and upper small intestine. Pediatr Res 1984; 18: 402-9.

26 Abrams CK, Hamosh M, Lee TC, et al. Gastric lipase: localization in human stomach. Gastroenterology 1988; 95: $1460-4$. 